\title{
Analisis Efektivitas Sistem Informasi Akuntansi Penggajian Karyawan Pada PT. Bank Pembiayaan Rakyat Al-Washliyah Medan
}

\author{
Yurmaini \\ Universitas Al Washliyah (UNIVA) Medan \\ yurmainiyus@yahoo.com
}

\begin{abstract}
Khairil Ashari
Sekolah Tinggi Ilmu Ekonomi International Business Management Indonesia (IBMI) Medan

khairilanshari2107@gmail.com
\end{abstract}

\begin{abstract}
This reseach aims to determine the effectiveness of Payroll Accounting Information Systems Employees at PT. Bank Pembiayaan Rakyat Syariah Alwashliyah Medan. PT. Bank Pembiayaan Rakyat Syariah Alwashliyah Medan is a bank finance institution based on sharia principles that accept deposits in the form of time deposits, savings and channeling funds as BPR business. To obtain the necessary data the researcher uses descriptive method with qualitative analysis. The data source used is using primary and secondary data. While to collect data researchers using observation techniques, interviews and literature. The results of research conducted by researchers, the effectiveness of payroll accounting information systems employees at PT. Bank Pembiayaan Rakyat Syariah Alwashliyah Medan has not run effectively yet. This can be seen from the documents used in the company is the absence of payroll slips on payroll. Companies only apply amprah salary which is listed on amprah book salary. The absence of a paycheck makes the employee unaware of how much the salary is earned and how much deductions are charged to the employee each month, making it difficult for the finance department to make a payroll report and not applying the employee's memorial and income statement as a document for the remuneration of payroll Accounting is difficult to keep a payroll journal.
\end{abstract}

Keywords: Effectiveness, Payroll Accounting Information System.

\footnotetext{
Abstrak

Penelitian ini bertujuan untuk mengetahui efektivitas Sistem Informasi Akuntansi Penggajian Karyawan di PT. Bank Pembiayaan Rakyat Syariah Medan. PT. Bank Pembiayaan Rakyat Syariah Alwashliyah Medan adalah lembaga keuangan bank
} 
berdasarkan prinsip syariah yang menerima deposito dalam bentuk deposito berjangka, tabungan dan dana penyaluran sebagai bisnis BPR. Untuk mendapatkan data yang diperlukan peneliti menggunakan metode deskriptif dengan analisis kualitatif. Sumber data yang digunakan adalah menggunakan data primer dan sekunder. Sedangkan untuk mengumpulkan data peneliti menggunakan teknik observasi, wawancara dan studi pustaka. Hasil penelitian yang dilakukan oleh peneliti, efektivitas sistem informasi akuntansi penggajian karyawan di PT. Bank Pembiayaan Rakyat Syariah Alwashliyah Medan belum berjalan secara efektif. Hal ini dapat dilihat dari dokumen yang digunakan di perusahaan adalah tidak adanya slip gaji pada daftar gaji. Perusahaan hanya menerapkan gaji amprah yang tercantum pada gaji buku amprah. Tidak adanya gaji membuat karyawan tidak menyadari berapa banyak gaji yang diterima dan berapa banyak pemotongan yang dibebankan kepada karyawan setiap bulan, sehingga menyulitkan departemen keuangan untuk membuat laporan penggajian dan tidak menerapkan memorial dan laporan pendapatan karyawan sebagai dokumen untuk remunerasi daftar gaji Akuntansi sulit untuk membuat jurnal penggajian.

\section{Kata Kunci: Efektivitas, Sistem Informasi Akuntansi Penggajian.}

\section{Pendahuluan}

Di era globalisasi sekarang ini, perusahaan dituntut untuk lebih efektif, efisien dan ekonomis dalam menentukan besarnya biaya operasional perusahaan. Karena faktor ini adalah salah satu terpenting untuk menghadapi persaingan yang semakin ketat dengan perusahaan lain. Perusahaan memanfaatkan kecanggihan teknologi untuk membantu mempermudah pekerjaan. Setiap perusahaan harus dikelola dengan baik agar tujuan yang dicapai oleh perusahaan dapat tercapai. Seiring dengan perkembangan ilmu pengetahuan dan teknologi berdampak pada perkembangan usaha, dalam hal ini akuntansi berperan penting sebagai penunjang kegiatan suatu perusahaan salah satunya adalah pemanfaatan sumber daya manusia dan pengembangan secara efektif dan efisien.

Sumber daya manusia atau tenaga kerja merupakan salah satu faktor penting dalam kegiatan perusahaan. Selain memberikan sumbangan kerja, tenaga kerja juga harus memberikan pemikiran dan keahliannya dalam operasional 
perusahaan. Tenaga kerja memiliki keterlibatan yang signifikan dalam suatu perusahaan, yaitu mulai dari menyusun dan merencanakan tujuan yang hendak dicapai baik dalam jangka pendek maupun jangka panjang. Bukan itu saja, dan setiap perusahaan akan membutuhkan jangka panjang untuk membiayai kegiatan usaha yang akan digunakan seefektif mungkin dan semakin luas. Seiring dengan bertambah luasnya aktifitas perusahaan, otomatis perusahaan tersebut akan menyebabkan kebocoran efisiensi dan ketidaktaatan terhadap prosedur yang ditetapkan perusahaan, salah satunya adalah gaji.

Gaji merupakan imbalan balas jasa atas usaha atau kerja yang telah dilakukan karyawan terhadap suatu perusahaan. Dalam memberikan gaji, setiap perusahaan memiliki sistem yang berbeda-beda. Dalam perhitungan gaji, terkadang perusahaan mengalami beberapa kesulitan dalam melakukannya. Kesulitan tersebut biasanya disebabkan karena banyaknya jumlah karyawan dan singkatnya waktu yang digunakan dalam perhitungan gaji. Pembayaran gaji merupakan salah satu unsur yang mudah menjadi sasaran kecurangan dan penggelapan dengan menggunakan berbagai cara. Dalam hal ini masalah penggajian merupakan hal yang sangat berperan penting di dalam suatu perusahaan.

Perusahaan diharapkan mampu menyediakan data dan laporan yang dapat dipercaya, dapat diuji serta menaati dan melaksanakan kebijakan-kebijakan yang telah ditetapkan. Peranan sistem sangat diperlukan agar aktifitas penggajian dapat berjalan dengan adanya sistem. Sistem terdiri dari kebijakan-kebijakan dan prosedur-prosedur yang dirancang untuk memberikan keyakinan kepada manajemen bahwa tujuan dan sasaran perusahaan dapat tercapai. Sistem tersebut kemudian menghasilkan informasi yang diperlukan perusahaan.

Salah satu informasi yang sangat diperlukan oleh perusahaan karena mampu memenuhi syarat informasi adalah sistem informasi akuntansi. Sistem informasi akuntansi merupakan salah satu sarana bagi manajemen untuk melakukan pengendalian intern yang berkaitan dengan penggajian agar pelaksanaannya dapat berjalan sesuai dengan rencana untuk mencapai tujuan yang telah ditetapkan sehingga sistem informasi akuntansi yang baik seharusnya diterapkan. Suatu sistem informasi akuntansi yang baik akan mendorong produktivitas yang tinggi dan memberikan kontribusi atas tercapainya tujuan 
perusahaan. Sistem informasi akuntansi berperan untuk menghindari kesalahankesalahan yang merugikan perusahaan dan dapat mencegah terjadinya penyimpangan dan penyelewengan.

PT. Bank Pembiayaan Rakyat Syariah Alwashliyah Medan adalah lembaga keuangan bank berdasarkan prinsip syariah yang menerima simpanan hanya dalam bentuk deposito berjangka, tabungan, dan bentuk lainnya yang dipersamakan dan menyalurkan dana sebagai usaha Bank Pembiayaan Rakyat, menyediakan pembiayaan bagi nasabah berdasarkan prinsip bagi hasil sesuai dengan ketentuan yang ditetapkan dalam peraturan pemerintah dan mempunyai karyawan sebanyak 21 orang.

Berdasarkan penelitian yang dilakukan peneliti bahwa sistem informasi akuntansi penggajian di dalam perusahaan belum menggunakan slip gaji. Perusahaan hanya menerapkan amprah gaji yang tertera pada buku amprah gaji. Secara teori, dokumen yang digunakan dalam sistem informasi akuntansi penggajian salah satunya adalah slip gaji. Slip gaji berisi jumlah gaji setiap karyawan serta dikurangi potongan-potongan PPh 21 dan lain-lain sebagainya. Slip gaji berguna untuk mengetahui seberapa besar gaji dan berapa banyak potongan yang akan diterima karyawan setiap bulannya.

Mengingat pentingnya gaji, maka sewajarnya bila sistem informasi akuntansi penggajian mendapat perhatian khusus dari pihak pimpinan perusahaan maka peneliti tertarik untuk melakukan penelitian dalam judul: "Analisis Efektivitas Sistem Informasi Akuntansi Penggajian Karyawan pada PT. Bank Pembiayaan Rakyat Syariah Alwashliyah Medan".

\section{Efektivitas}

Efektivitas adalah tercapainya atau berhasilnya suatu sasaran atau tujuan yang telah ditentukan suatu perusahaan dengan menjalankan pekerjaan yang benar dari sebelumnya yang merupakan sebuah pengukuran dimana suatu target dan sasaran telah tercapai dan ditetapkan sesuai dengan apa yang direncanakan dalam suatu perusahaan secara tepat. Setiap organisasi atau perusahaan didalam kegiatannya menginginkan adanya pencapaian tujuan. Tujuan dari suatu perusahaan akan tercapai segala kegiatannya dengan berjalan efektif akan dapat dilaksanakan apabila didukung oleh faktor-faktor pendukung efektivitas. Upaya 
mengevaluasi jalannya suatu organisasi, dapat dilakukan melalui konsep efektivitas. Konsep ini adalah salah satu faktor untuk menentukan perusahaan akan membutuhkan untuk membiayai kegiatan usaha yang akan digunakan apakah perlu dilakukan perubahan secara signifikan terhadap bentuk dan manajemen organisasi atau tidak.

Dalam hal ini efektivitas merupakan pencapai tujuan organisasi melalui pemanfaatan sumber daya yang dimiliki secara efisien, ditinjau dari sisi masukan (input), proses maupun keluaran (output) yang dimaksud adalah sumber daya meliputi ketersediaan personil, sarana dan prasarana serta metode yang digunakan. Suatu kegiatan dikatakan efektif apabila kegiatan tersebut dilaksanakan dengan benar dan memberikan hasil yang bermanfaat. Suatu perusahaan pasti mempunyai tujuan yang hendak dicapai, pelaksanaan tujuan tersebut merupakan tugas dan tanggung jawab dari pihak manajemen. Agar tujuan yang ditetapkan oleh manajemen dalam suatu perusahaan dapat tercapai secara optimal, maka perlu adanya pengawasan atau pengendalian intern yang baik adalah efektivitas. Efektivitas adalah bagaimana suatu organisasi berhasil mendapatkan dan memanfaatkan sumber daya dalam usaha mewujudkan tujuan operasional.

Sistem informasi merupakan sebuah susunan dari orang, aktivitas, data, jaringan dan teknologi yang terintegrasi yang berfungsi untuk mendukung dan meningkatkan operasi sehari-hari bisnis, juga menyediakan kebutuhan informasi untuk memecahkan masalah dan pengambilan keputusan oleh manajer. Kebutuhan akan informasi telah mendorong perkembangan akuntansi sebagai suatu sistem informasi. Sistem informasi akuntansi dikatakan efektif apabila penyelenggaraan sistem informasi tersebut telah memberikan manfaat sesuai dengan target dan tujuan yang telah ditetapkan sebelumnya.

\section{Sistem Informasi Akuntansi}

Sistem akuntansi dibuat bertujuan untuk menghasilkan informasi. Informasi tersebut dapat berupa laporan keuangan untuk keperluan manajerial dalam mengambil keputusan. Kebutuhan akan informasi yang dapat digunakan untuk menentukan tindakan yang harus diambil dalam sebuah keputusan. Sistem informasi menerima input yang biasa disebut dengan nama transaksi suatu sistem, yang kemudian diajukan atau dikirim melalui berbagai proses menjadi output 
informasi yang akan didistribusikan kepada para pemakai informasi yang akan mencatat dan mengolah data transaksi dan menyajikan informasi kepada pihakpihak yang berhak dan berkepentingan untuk dibidang sistem informasi suatu perusahaan. Sistem informasi akuntansi terdiri dari lima komponen antara lain:

1. Orang-orang yang mengoperasikan sistem tersebut dan melaksanakan berbagai fungsi.

2. Prosedur-prosedur, baik manual maupun yang terotomatis, yang dilibatkan dalam mengumpulkan, memproses dan menyimpan data tentang aktivitasaktivitas organisasi.

3. Data tentang proses-proses bisnis organisasi.

4. Software yang dipakai untuk memproses data organisasi.

5. Infrastruktur teknologi informasi, termasuk komputer, peralatan pendukung (peripheral device), dan peralatan untuk komunikasi jaringan

Setiap tindakan yang perusahaan yang baik akan mempunyai arah yang jelas. Sistem informasi akuntansi penggajian dalam perusahaan dapat berjalan dengan baik apabila melibatkan fungsi kepegawaian, fungsi keuangan dan fungsi akuntansi. Menurut Mulyadi, catatan akuntansi yang digunakan dalam pencatatan penggajian adalah sebagai berikut ${ }^{1}$ :

1. Jurnal umum

Dalam pencatatan gaji ini jurnal umum digunakan untuk mencatat distribusi biaya tenaga kerja kedalam setiap departemen dalam perusahaan.

2. Kartu harga pokok produk

Catatan ini digunakan untuk mencatat upah tenaga kerja langsung yang dikeluarkan untuk peranan tertentu.

3. Kartu biaya

Catatan ini digunakan untuk mencatat biaya tenaga kerja tidak langsung dan biaya tenaga kerja non produksi setiap departemen dalam perusahaan. sumber informasi untuk pencatatan dalam kartu biaya ini adalah bukti memorial.

4. Kartu penghasilan karyawan

Catatan ini digunakan untuk mencatat penghasilan dan berbagai potongannya yang diterima oleh setiap karyawan.

Menurut Mulyadi, sistem penggajian terdiri dari jaringan prosedur berikut ini $^{2}$ : 
1. Prosedur pencatatan waktu

Prosedur ini bertujuan untuk mencatat waktu hadir karyawan yang diselenggarakan oleh fungsi pencatat waktu dengan menggunakan daftar hadir pada pintu masuk. Pencatatan waktu hadir dapat menggunakan daftar hadir biasa atau menggunakan kartu hadir yang diisi secara otomatis dengan menggunakan mesin pencatat waktu.

Prosedur pembuatan daftar gaji

Fungsi pembuat daftar gaji membuat daftar gaji karyawan. Data yang dipakai sebagai dasar pembuatan daftar gaji adalah surat-surat keputusan mengenai pengangkatan karyawan baru, kenaikan pangkat, pemberhentian karyawan, penurunan pangkat daftar gaji bulan sebelumnya, dan daftar hadir.

3. Prosedur distribusi biaya gaji

Dalam distribusi biaya gaji, biaya tenaga kerja didistribusikan kepada departemen-departemen yang menikmati manfaat tenaga kerja. Ini dimaksudkan untuk pengendalian intern dan perhitungan harga pokok produk.

4. Prosedur pembuatan bukti kas keluar.

Biaya tenaga kerja didistribusikan kepada departemen-departemen yang menikmati manfaat tenaga kerja. Ini dimaksudkan untuk pengendalian biaya dan perhitungan harga pokok produksi.

\section{Prosedur pembayaran gaji}

Prosedur pembayaran gaji melibatkan fungsi akuntansi dan fungsi keuangan. Fungsi akuntansi melibatkan perintah pengeluaran kas ke fungsi keuangan agar ditulis cek dan fungsi keuangan mencairkan cek ke bank untuk pembayaran gaji

Sistem informasi akuntansi gaji dan upah juga dirancang oleh perusahaan untuk memberikan gambaran yang jelas mengenai gaji dan upah karyawan sehingga mudah dipahami dan mudah digunakan. Dan mengatasi adanya kesalahan dan penyimpangan dalam perhitungan maupun pembayaran gaji. Sistem informasi akuntansi penggajian dapat digunakan oleh manajemen perusahaan untuk merencanakan dan mengendalikan operasi perusahaan. Menurut Romney dan Steinbart di dalam penggajian ada tujuh aktifitas dasar yang dilakukan diantaranya adalah sebagai berikut ${ }^{3}$ :

1. Perbaharui file induk penggajian 
Dalam siklus penggajian melibatkan pembaharuan file induk penggajian untuk mencerminkan berbagai jenis perubahan penggajian.

2. Memperbaharui tarif gaji dan pemotongan pajak.

Memperbaharui informasi mengenai tarif dan pemotongan pajak lainnya.

3. Validasi data waktu dan kehadiran

Memvalidasi setiap data waktu dan kehadiran pegawai dalam berbagai bentuk.

4. Mempersiapkan penggajian

Departemen tempat pegawai bekerja akan mengenai data mengenai jam yang dihabiskan dan kemudian mengkonfirmasikan data tersebut.

5. Membayar gaji

Melakukan pembayaran gaji dengan menggunakan cek atau dengan penyimpanan langsung gaji bersih kerekening karyawan.

6. Hitung kompensasi dan pajak yang dibayar perusahaan

Perusahaan membayar beberapa pajak penghasilan dan kompensasi pegawai secara langsung.

7. Mengeluarkan pajak penghasilan dan potongan lain-lain.

Membayar kewajiban pajak secara periodik membuat cek atau menggunakan transfer dana secara elektronis untuk membayar kewajiban pajak yang terjadi.

Sistem akuntansi yang digunakan suatu perusahaan untuk menangani pembayaran atas penyerahan jasa yang dilakukan oleh karyawan yang mempunyai jenjang jabatan manajer.

\section{Sistem Informasi Akutansi Penggajian}

Menurut Mulyadi : "Sistem akuntansi penggajian dirancang untuk menangani transaksi perhitungan gaji dan upah karyawan dan pembayarannya. Sistem ini terdiri dari jaringan prosedur antara lain prosedur pencatatan waktu hadir dan kerja, pembuatan daftar gaji, pembayaran gaji dan distribusi biaya gaji." 4

Dalam menjalankan aktivitas yang dilakukan oleh perusahaan, tenaga kerja atau karyawan merupakan salah satu faktor penting yang mempengaruhi kesuksesan dalam menjalankan aktivitas tersebut. Tenaga kerja yang telah berkontribusi terhadap kegiatan perusahaan diberikan penghargaan yang disebut dengan gaji. Gaji sangat penting bagi karyawan karena dapat memberikan 
pengaruh terhadap kepuasan karyawan sehingga dapat memotivasi dan merangsang karyawan bekerja lebih giat.

Gaji merupakan suatu bentuk balas jasa ataupun penghargaan yang diberikan secara teratur kepada seorang atas jasa dan hasil kerjanya. Gaji sering juga disebut sebagai upah, dimana keduanya merupakan suatu bentuk kompensasi. Pemberian gaji karyawan baik secara langsung atau tidak didasarkan dan dibatasi oleh produktivitas dan keahlian sumber daya manusianya serta tingkat jabatan karyawan. Karena gaji merupakan unsur yang sangat penting bagi perusahaan, maka diperlukan suatu sistem yang dapat mengelola gaji secara baik.

Sistem penggajian merupakan suatu jaringan prosedur yang dibuat secara terpadu untuk menghasilkan informasi mengenai gaji pegawai secara akurat dan memadai sehingga informasi tersebut dapat berguna bagi pihak-pihak yang memerlukan. Sistem penggajian yang baik merupakan sistem yang mampu memotivasi karyawannya untuk bekerja lebih baik lagi guna untuk mencapai tujuan perusahaan.

Sistem informasi akuntansi gaji dan upah juga dirancang oleh perusahaan untuk memberikan gambaran yang jelas mengenai gaji dan upah karyawan sehingga mudah dipahami dan mudah digunakan. Dan mengatasi adanya kesalahan dan penyimpangan dalam perhitungan maupun pembayaran gaji. Sistem informasi akuntansi penggajian dapat digunakan oleh manajemen perusahaan untuk merencanakan dan mengendalikan operasi perusahaan. Menurut Mulyadi, juga menjelaskan bahwa unsur-unsur pokok pengendalian intern dalam sistem akuntansi penggajian adalah sebagai berikut ${ }^{5}$ :

1. Organisasi

a. Fungsi pembuatan daftar gaji harus terpisah dari keuangan.

b. Fungsi pencatatan waktu hadir harus terpisah dari fungsi operasi.

2. Sistem Otorisasi

a. Setiap orang namanya tercantum dalam daftar gaji harus memiliki surat keputusan pengangkatan sebagai karyawan perusahaan yang ditandatangani oleh direktur utama.

b. Setiap perubahan gaji karyawan karena perubahan pangkat, perubahan tarif gaji, tambahan keluarga harus didasarkan pada keputusan direktur keuangan. 
c. Setiap potongan atas gaji karyawan selain dari pajak penghasilan karyawan harus didasarkan atas surat potongan gaji yang diotorisasi oleh fungsi kepegawaian.

d. Kartu jam hadir harus diotorisasi oleh fungsi pencatat waktu.

e. Perintah lembur harus diotorisasi oleh kepala departemen karyawan yang bersangkutan.

f. Daftar gaji harus diotorisasi oleh fungsi personalia

g. Bukti kas keluar untuk pembayaran gaji harus diotorisasi oleh fungsi akuntansi.

3. Prosedur Pencatatan

a. Perubahan dalam catatan penghasilan kartu karyawan direkonsiliasi dengan daftar gaji karyawan.

b. Tarif upah yang dicantumkan dalam kartu jam diverifikasi ketelitiannya oleh fungsi akuntansi.

4. Praktik yang sehat

a. Kartu jam hadir harus dibandingkan dengan kartu jam kerja sebelum kartu yang terakhir ini dipakai sebagai dasar distribusi biaya tenaga kerja langsung.

b. Pemasukan kartu jam hadir kedalam mesin pencatat waktu harus diawasi oleh fungsi pencatat waktu.

c. Pembuatan daftar gaji harus diverifikasi kebenaran dan ketelitian perhitungannya oleh fungsi akuntansi sebelum dilakukan pembayaran.

d. Perhitungan pajak penghasilan karyawan direkonsiliasi dengan catatan penghasilan karyawan.

e. Catatan penghasilan karyawan disimpan oleh fungsi pembuat daftar gaji

Uraian sistem penggajian yang merupakan sistem pembayaran jasa yang diserahkan oleh karyawan yang bekerja sebagai manajer atau kepada karyawan yang gajinya dibayarkan bulanan, tidak tergantung dari jumlah jam atau hari kerja atau jumlah produk yang dihasilkan. Oleh karena itu, dalam sistem penggajian ini tidak diperlukan pencatatan waktu kerja, karena biaya tenaga kerja yang dikeluarkan oleh perusahaan tidak perlu dibebankan langsung kepada produk. Dalam sistem penggajian berikut ini, tanda terima gaji oleh karyawan dibuktikan dengan penandatangan oleh karyawan atas kartu penghasilan karyawan, sehingga 
setiap karyawan hanya dapat melihat gajinya masing-masing. Informasi gaji merupakan informasi pribadi, yang bersifat rahasia bagi karyawan lain.

Bagan Alir Dokumen Sistem Informasi Akuntansi Penggajian atau flowchart memiliki beberapa lambang yang sudah biasa digunakan dalam pengembangan sistem, baik dalam sistem manual maupun sistem komputerisasi. Flowchart pada awalnya digunakan untuk aplikasi pemrograman komputer, karena pada waktu itu menggunakan komputer masih sangat mahal, sehingga untuk menyusun komputer harus dibuat logika programnya dengan memanfaatkan flowchart. Bagan alir data atau flowchart adalah suatu model yang menggambarkan aliran data dan proses untuk mengolah data dalam suatu sistem.

Simbol-simbol standar yang digunakan untuk menggambarkan bagan alir data. Untuk menggambarkan dokumen flowchart dalam sistem tertentu, digunakan simbol-simbol tersebut dalam suatu bagan alir dokumen. Dalam bagian alir, arus dokumen digambarkan berjalan dari kiri ke kanan dan dari atas ke bawah. Arah perjalanan dokumen ini dapat diikuti dengan melihat nomor dalam simbol penghubung pada halaman yang sama atau nomor pada simbol penghubung pada halaman yang berbeda.

Tabel 1 Simbol pada Bagan Alir Dokumen (Flowchart)

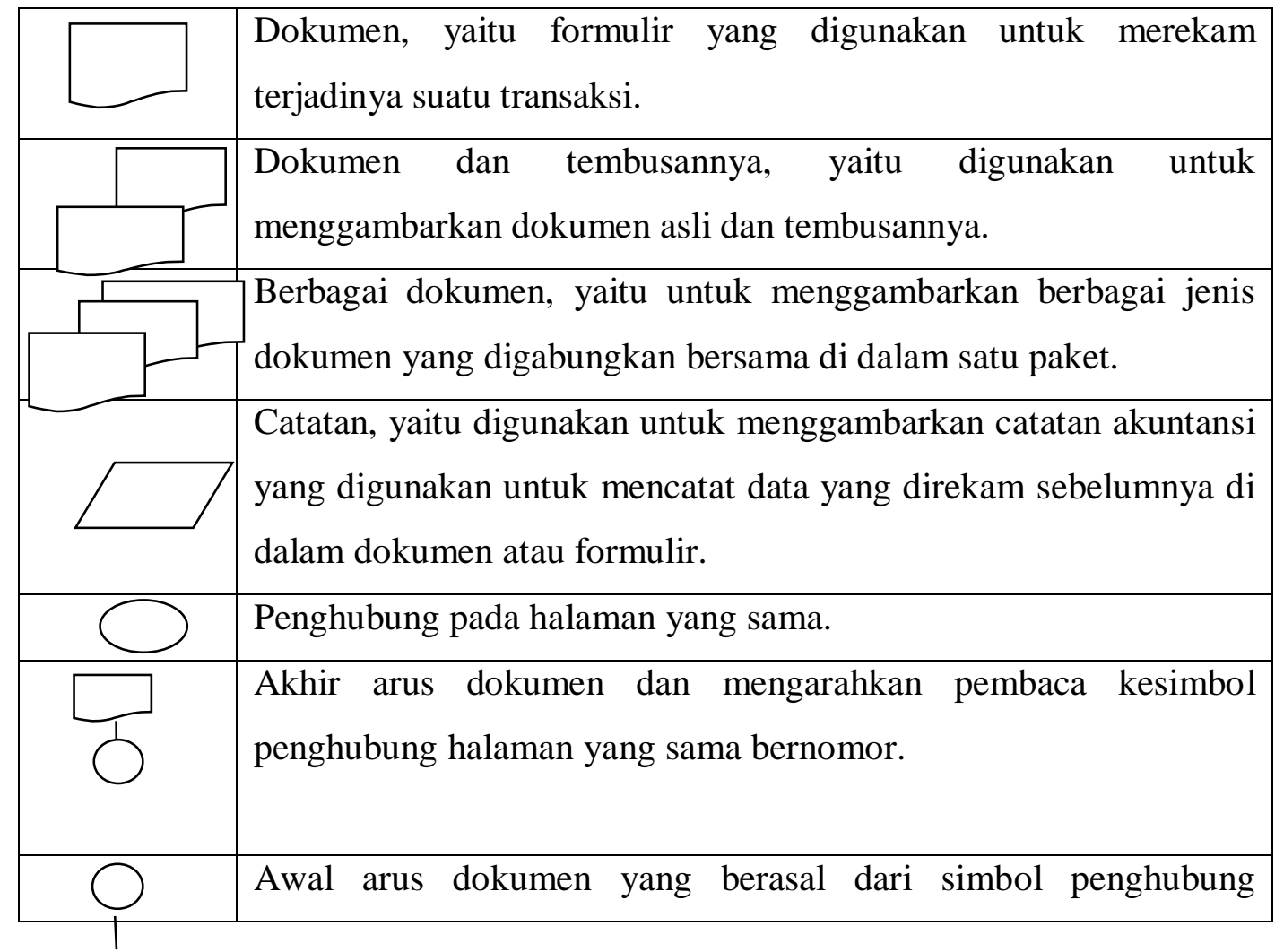


Yurmaini dan Khairil: Analisis Efektivitas Sistem Informasi Akuntansi 425

\begin{tabular}{|l|l|}
\hline$\square$ & halaman yang sama. \\
\hline$\square$ & $\begin{array}{l}\text { Penghubung pada halaman yang berbeda, yaitu menunjukkan } \\
\text { kemana dan bagaimana bagan alir terkait satu dengan yang } \\
\text { lainnya. }\end{array}$ \\
\hline$\square$ & $\begin{array}{l}\text { Kegiatan manual, yaitu menggambarkan kegiatan manual. } \\
\text { dengan komputer secara on-line. }\end{array}$ \\
\hline$\square$ & $\begin{array}{l}\text { Arsip permanen, tempat penyimpanan dokumen yang tidak akan } \\
\text { diproses lagi dalam sistem akuntansi yang bersangkutan. }\end{array}$ \\
\hline$\square$ & $\begin{array}{l}\text { Garis alir (Flowline), digunakan untuk menggambarkan arah } \\
\text { proses pengolahan data. }\end{array}$ \\
\hline$\square$ & $\begin{array}{l}\text { Mulai/berakhir, digunakan untuk menggambarkan awal dan akhir } \\
\text { suatu sistem akuntansi. }\end{array}$ \\
\hline$\square$
\end{tabular}

Sumber : Mulyadi. ${ }^{6}$

Penggunaan bagan alir dokumen atau flowchart lebih bermanfaat dibanding dengan uraian tertulis dalam menggambarkan suatu sistem. Adapun manfaat dari bagan alir dokumen atau flowchart adalah sebagai berikut:

1. Gambaran sistem secara menyeluruh lebih mudah diperoleh dengan menggunakan bagan aliran.

2. Perubahan sistem lebih mudah digambarkan atapun dijelaskan dengan menggunakan bagan alir.

3. Kelemahan-kelemahan dalam sistem dan identifikasi bidang-bidang yang memerlukan perbaikan lebih mudah ditemukan dengan bagan alir.

4. Dokumentasi sistem akuntansi dilakukan dengan menggunakan bagan alir.

\section{Metodologi Penelitian}

Dalam penelitian ini jenis penelitian yang digunakan adalah penelitian deskriptif. Penelitian deskriptif adalah salah satu jenis penelitian yang tujuannya untuk menyajikan gambaran lengkap mengenai keadaan atau dimaksudkan untuk klarifikasi mengenai suatu fenomena atau kenyataan yang ada, dengan jalan 
mendeskripsikan sejumlah variabel yang berkenaan dengan masalah dan unit yang diteliti dengan fenomena yang diuji.

Sumber data yang digunakan adalah sumber data Primer dan data sekunder sebagaimana yang dijabarkan sebagai berikut:

1. Data Primer

Data primer merupakan data yang secara langsung diperoleh dari sumbernya aslinya. Peneliti memperoleh data langsung dari perusahaan, dalam hal ini berupa penjelasan dan penjabaran yang diungkapkan dari pihak manajemen mengenai prosedur sistem informasi akuntansi penggajian karyawan yang dilakukan pada PT. Bank Pembiayaan Rakyat Syariah Alwashliyah Medan.

\section{Data Sekunder}

Data sekunder adalah data yang diperoleh peneliti secara tidak langsung melalui media perantara atau dari sumber lain dan dikumpulkan untuk suatu maksud media perantara atau dari sumber lain dan dikumpulkan untuk suatu maksud tertentu. Data sekunder terdiri dari dua yaitu internal dan eksternal. Data internal yaitu data organisasi seperti struktur organisasi, sejarah perusahaan dan laporan penggajian karyawan, sedangkan data eksternal yaitu data yang diperoleh dari terbitan berkala (jurnal ilmiah), buku, dokumen dan internet yang berisikan tentang sistem informasi akuntansi penggajian. Dalam hal ini peneliti memperoleh data sekunder eksternal yaitu dari buku, internet dan dokumen-dokumen yang ada hubungannya dengan masalah yang ada diperusahaan tersebut.

Untuk mendapatkan data dan keterangan akurat yang diperlukan dalam penyusunan penelitian ini, peneliti menggunakan metode pengumpulan data sebagai berikut:

\section{Observasi}

Observasi adalah pengamatan langsung para pembuat keputusan berikut lingkungan fisiknya dan atau pengamatan langsung suatu kegiatan yang sedang berjalan.

2. Wawancara

Wawancara adalah tanya-jawab dengan seseorang untuk mendapatkan keterangan pendapatnya tentang suatu hal atau masalah.

3. Kepustakaan 
Yurmaini dan Khairil: Analisis Efektivitas Sistem Informasi Akuntansi $\mid 427$

Membaca dan mempelajari buku-buku bacaan, bahan kuliah dan ilmiah lainnya yang berkaitan erat dengan penulisan skripsi.

\section{Teknik Analisis Data}

Teknik analisis data yang digunakan dalam penelitian ini adalah deskriptif kualitatif. Analisis data dimulai dengan mengumpulkan data yang tersedia dari berbagai sumber yang diperoleh peneliti dari perusahaan. Selanjutnya peneliti mendeskripsikan beberapa konsep praktis berdasarkan pemahaman yang diperoleh secara langsung. Konsep praktis tersebut kemudian dideskripsikan dengan cara membandingkan temuan atau pemahaman atas kenyataan yang terdapat dalam sistem informasi akuntansi penggajian pada PT. Bank Pembiayaan Rakyat Syariah Alwashliyah Medan dengan konsep atau teori yang berhubungan dengan sistem tersebut. Pada tahap selanjutnya peneliti mengevaluasi konsep praktis organisasi dengan melihat fakta yang ada berbagai akibat yang muncul di dalam sistem kegiatan operasional perusahaan dan kemudian ditarik kesimpulan untuk menjawab permasalahan yang muncul dalam sistem informasi akuntansi penggajian pada PT. Bank Pembiayaan Rakyat Syariah Alwashliyah Medan.

\section{Sejarah Perusahaan PT BPRS Al-Washliyah}

Periode I beroperasi sejak tanggal 08 November 1994, yang semula berkedudukan di jalan Perintis Kemerdekaan No. 151 A Tanjung Morawa. Diresmikan oleh Gubernur Sumatra Utara H. Raja Inal Siregar. Sebagai Direktur Utama H. Suprapto, dan sebagai komisaris Ir. H. M. Arifin Kamdi.Msi, H. Maslin Batu Bara, Khalifah Sitohang, Hidayatullah,SE, H. Murat Hasyim. Pada periode II dibentuk nama struktur organisasi baru yaitu : Direktur Utama H. T.Kholisbah, dan sebagai Komisaris Ir.H. M. Arifin Kamdi M.si, H. Maslim Batu Bara, Khalifah Sitohang, Hidayatullah,SE, Drs. H. Miftahuddin MBA. Dan periode III pada tanggal 02 April 2003 kantor PT. BPR Syariah Al Washliyah telah berpindah di jalan SM. Raja NO 51D Sp. Limun Medan, yang diresmikan oleh Gubernur Sumatra Utara yakni H. T. Rizal Nurdin. Sebagai Direktur Utama Hidayatullah,SE, dan Komisaris adalah Ir. H. M. Arifin Kamdi. M.si, Drs.H. Miftahuddin MBA. Bank menjalankan operasinya berdasarkan Syariah Islam, dengan menjauhi praktek-praktek yang dikhawatirkan mengandung riba dan sejak 
tahun 2013 telah memiliki gedung baru di jalan G. Krakatau No 28 Medan, yang diresmikan oleh Gubernur Sumatra Utara yakni H. Gatot Pudjonugroho pada tanggal 06 Januari 2014. Sebagai Komisaris Drs. H. Hasbullah Hadi,SH.MKn dan Drs. H. Miftahuddin MBA. Dewan Pengawas Syariah adalah Dr. H. Ramli Abd. Wahid. M.A. sebagai Direktur Utama H.R. Bambang Risbagio,SE dan Direktur Operasional.

\section{Arti Logo Perusahaan}

Arti dari Logo pada PT. Bank Pembiayaan Rakyat Syariah Alwashliyah Medan melambangkan :

> Yang berbentuk bendera: Lembaran uang yang melambangkan aktivitas ekonomi di bidang perbankan.

> Warna hijau pada lembaran uang: Bertuliskan tulisan AL WASHLIYAH.

$>$ Pada lembaran uang tersebut terdapat tulisan (AW), itu adalah identitas PT. BPR SYARIAH AL WASHLIYAH.

> Terdapat gambar bintang pada lembaran uang tersebut yang melambangkan bahwa bank tersebut bisa bersinar terang di tempat yang tinggi layaknya bintang.

$>$ Bintang tersebut berwarna emas yang melambangkan kesuksesan atau kejayaan PT. BPRS AL WASLIYAH.

\section{Visi dan Misi Perusahaan}

a. Visi: "Menjadikan BPR Syariah sebagai sarana untuk mencapai kesejahteraan ummat"

b. Misi:

- Memberikan pelayanan yang optimal berdasarkan prinsip syariah dengan mengutamakan kepuasan.

- Menjalankan bisnis yang sehat, serta melahirkan ide-ide inovatif untuk mendorong usaha bersama.

c. Tujuan: utama manajemen PT. BPR Syariah Al-Washliyah adalah merencanakan dan mengatur perusahaan untuk menambah penghasilan dan meningkatkan profit dan falah oriented.

\section{Struktur Organisasi}


Yurmaini dan Khairil: Analisis Efektivitas Sistem Informasi Akuntansi $\mid 429$

Struktur organisasi adalah kerangka dasar yang mempersatukan fungsifungsi suatu perusahaan yang mengakibatkan timbulnya hubungan-hubungan antara personil yang melaksanakan fungsi atau tugas masing-masing, dan merupakan gambaran tentang pembagian bidang kegiatan dan pendelegasian tugas, wewenang dan tanggung jawab. Adapun struktur organisasi PT. BPRS Syari'ah Al-Washliyah Medan sebagai berikut:

Gambar 1 Struktur Organisasi PT. BPRS Syari'ah Al-Washliyah Medan

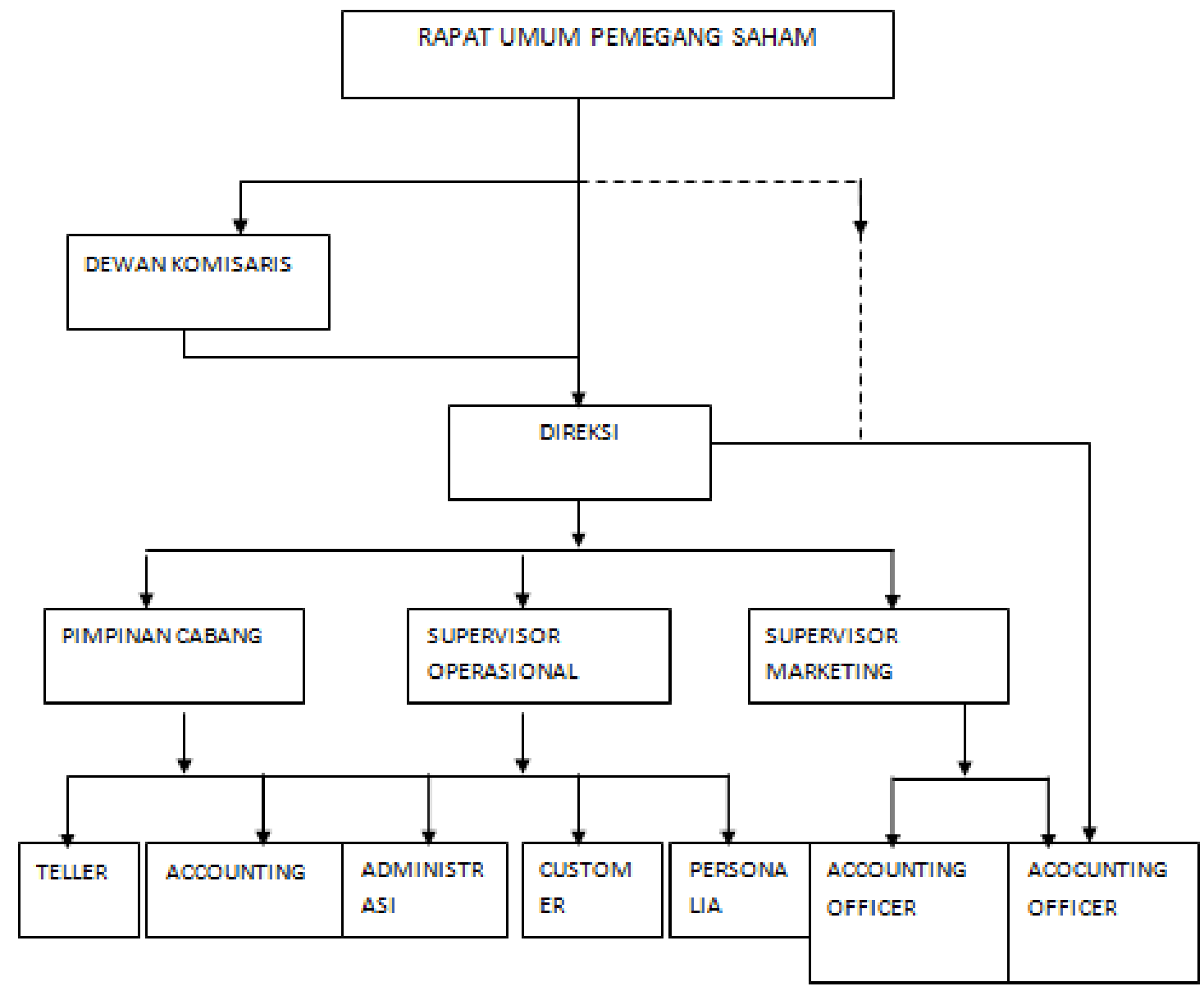

Adapun bagian yang terkait atau menangani dalam sistem penggajian pada PT.

Bank Pembiayaan Rakyat Syariah Alwashliyah Medan adalah sebagai berikut:

1. Bagian Kepegawaian

Bagian kepegawaian bertanggung jawab dalam menyeleksi karyawan, memutuskan penempatan kerja, membuat surat keputusan tarif gaji karyawan, kenaikan pangkat serta pemberhentian karyawan yang dilakukan oleh direksi.

2. Bagian Pembuat Daftar Gaji 
Bagian pembuat daftar gaji bertanggungjawab dalam membuat daftar gaji berdasarkan gaji pokok bagi semua karyawan PT. Bank Pembiayaan Rakyat Syariah Alwashliyah Medan yang dilakukan oleh personalia.

3. Bagian Keuangan

Bagian keuangan bertanggung jawab dalam membayarkan gaji karyawan yang ditransfer melalui ke rekening masing-masing karyawan PT. Bank Pembiayaan Rakyat Syariah Alwashliyah Medan yang dilakukan setiap bulannya. Bagian keuangan ini dilakukan oleh personalia.

4. Bagian Akuntansi

Bagian akuntansi bertanggung jawab atas semua pencatatan biaya gaji dan membuat jurnal penggajian yang ada pada PT. Bank Pembiayaan Rakyat Syariah Alwashliyah Medan dan pencatatan biaya gaji tersebut dilakukan oleh personalia.

Dokumen yang digunakan dalam sistem informasi akuntansi penggajian pada PT. Bank Pembiayaan Rakyat Syariah Alwashliyah Medan adalah sebagai berikut:

\section{Dokumen Pendukung Perubahan Gaji}

Dokumen-dokumen perubahan gaji dikeluarkan oleh direksi, dokumen ini berupa surat keputusan yang bersangkutan dengan karyawan. Dokumen ini dapat berupa surat pengangkatan karyawan baru, kenaikan gaji dan surat pemberhentian sementara dari pekerjaan, kemudian diserahkan kepada dewan komisaris untuk disetujui.

\section{Kartu Jam Hadir}

Kartu jam hadir dibuat untuk masing-masing karyawan yang menunjukkan pada saat jam datang dan pulang karyawan. Kartu ini dimasukkan dalam mesin pencatat waktu pada waktu karyawan datang maupun pulang sehingga tercetak jam datang dan jam pulang.

\section{Surat Perintah Lembur Karyawan}

Dokumen ini memuat perintah yang diberikan kepada karyawan PT. Bank Pembiayaan Rakyat Syariah Alwashliyah Medan untuk kerja lembur sebagai perhitungan tunjangan lembur.

4. Amprah Gaji 
Dokumen ini dibuat oleh personalia yang berisi jumlah gaji karyawan yang tertera pada buku untuk ditandatangani karyawan pada saat pengambilan gaji yang dilakukannya setiap bulan.

5. Rekap Gaji

Dokumen ini dibuat oleh personalia dan merupakan ringkasan gaji yang dibuat berdasarkan amprah gaji karyawan PT. Bank Pembiayaan Rakyat Syariah Alwashliyah Medan.

6. Bukti Kas Keluar

Dokumen ini dibuat oleh personalia berdasarkan informasi dalam amprah gaji. Dokumen tersebut digunakan sebagai dasar bukti kas keluar untuk pencatatan penggajian karyawan PT. Bank Pembiayaan Rakyat Syariah Alwashliyah Medan.

Keberhasilan suatu perusahaan didukung sebagai salah satunya adalah dari faktor tenaga kerja yang perlu mendapatkan perhatian khusus terutama dalam hal penggajian. Dengan adanya penggajian kepada tenaga kerja maka perusahaan menanggung biaya gaji yang merupakan unsur utama dari pengeluaran perusahaan pada PT. Bank Pembiayaan Rakyat Syariah Alwashliyah Medan. Biaya gaji merupakan unsur yang sangat relatif besar dan mempunyai resiko kemungkinan terjadinya manipulasi, kecurangan dan penyelewengan.

Salah satu usaha PT. Bank Pembiayaan Rakyat Syariah Alwashliyah Medan adalah untuk menghindari terjadinya resiko tersebut adalah dengan adanya sistem informasi akuntansi penggajian yang baik dan benar. Sistem informasi akuntansi penggajian karyawan yang diterapkan pada PT. Bank Pembiayaan Rakyat Syariah Alwashliyah Medan adalah bulanan, tidak menggunakan sistem upah harian. Gaji dibayarkan kepada pegawai yang benarbenar tercatat sebagai yang sah dalam daftar induk kepegawaian.

PT. Bank Pembiayaan Rakyat Syariah Alwashliyah Medan bagian pembuat daftar gaji, keuangan dan akuntansi tidak terpisah menjadi bagian sendiri karena pembuatan daftar gaji, pembayaran gaji dan pencatatan penggajian ditangani langsung oleh bagian personalia. Hal ini disebabkan karena kurangnya pegawai dalam menangani penggajian karyawan yang menyebabkan laporan penggajian yang diserahkan dan pencatatan gaji memakan waktu yang lama dan mengurangi efektifitas dan efisiensi penggajian dalam perusahaan. Dokumen yang 
digunakan dalam sistem informasi akuntansi penggajian pada PT. Bank Pembiayaan Rakyat Syariah Alwashliyah Medan antara lain dokumen pendukung perubahan gaji, kartu jam hadir karyawan, surat perintah lembur, rekap gaji, amprah gaji dan bukti kas keluar. Sedangkan menurut teori dokumen yang digunakan dalam sistem informasi akuntansi penggajian adalah dokumen pendukung perubahan gaji, kartu jam hadir, kartu jam kerja, daftar gaji karyawan, rekap daftar gaji, surat pernyataan gaji, amplop gaji dan bukti kas keluar.

PT. Bank Pembiayaan Rakyat Syariah Alwashliyah Medan tidak menggunakan kartu jam kerja tetapi menggunakan kartu jam hadir untuk mencatat kehadiran karyawan. Dokumen pendukung yang digunakan dalam perusahaan hanya merupakan perubahan gaji yang meliputi pengangkatan karyawan baru, kenaikan/penurunan pangkat dan lain-lain. Surat penyataan gaji dan slip gaji juga tidak digunakan dalam perusahaan karena catatan mengenai rincian gaji yang akan diterima karyawan hanya berdasarkan buku amprah gaji. Penggajian dilakukan dengan sistem transfer dan kemudian karyawan menanda tangani buku amprah gaji tersebut setiap bulannya.

Dokumen yang digunakan untuk proses pembayaran gaji pada PT. Bank Pembiayaan Rakyat Syariah Alwashliyah Medan belum efektif, dimana pada saat pengambilan gaji yang dilakukan dengan sistem transfer ke rekening masingmasing karyawan, karyawan tidak diberikan slip gaji. Karyawan hanya menanda tangani amprah pada buku amprah gaji dan karyawan hanya mengetahui jumlah gaji yang diterima namun untuk potongan gaji, karyawan yang bersangkutan tidak mengetahuinya. Tidak digunakannya slip gaji bagian keuangan sulit dalam membuat bukti laporan penggajian.

Catatan akuntansi yang digunakan dalam sistem informasi akuntansi penggajian pada PT. Bank Pembiayaan Rakyat Syariah Alwashliyah Medan hanya menggunakan jurnal umum. Menurut teori pada bagian akuntansi sistem informasi penggajian bagian akuntansi terdapat bukti memorial dan kartu penghasilan karyawan. Dalam melakukan penjurnalan penggajian PT. Bank Pembiayaan Rakyat Syariah Alwashliyah Medan belum menerapkan bukti memorial dan kartu penghasilan karyawan sebagai dokumen untuk pencatatan penggajian. 
Yurmaini dan Khairil: Analisis Efektivitas Sistem Informasi Akuntansi 433

\section{Kesimpulan}

Berdasarkan hasil penelitian dan pembahasan terhadap efektivitas sistem informasi akuntansi penggajian karyawan pada PT. Bank Pembiayaan Rakyat Syariah Alwashliyah Medan dapat disimpulkan bahwa:

1. Bagian yang terkait didalam sistem penggajian seperti bagian pembuat daftar gaji, bagian keuangan dan bagian akuntansi tidak terpisah menjadi bagian tersendiri. Karena pembuatan daftar gaji, pembayaran gaji dan pencatatan penggajian ditangani langsung oleh bagian personalia dan menyebabkan laporan penggajian yang diserahkan dan pencatatan gaji memakan waktu yang lama juga mengurangi efektifitas dan efisiensi penggajian dalam perusahaan.

2. Dokumen yang digunakan untuk proses pembayaran gaji pada PT. Bank Pembiayaan Rakyat Syariah Alwashliyah Medan belum efektif, dimana pada saat pengambilan gaji yang dilakukan dengan sistem transfer ke rekening masing-masing karyawan, karyawan tidak diberikan slip gaji. Karyawan hanya menandatangani amprah pada buku amprah gaji dan karyawan hanya mengetahui jumlah gaji yang diterima namun untuk potongan gaji, karyawan yang bersangkutan tidak mengetahuinya. Tidak digunakannya slip gaji bagian keuangan sulit dalam membuat bukti laporan penggajian.

3. Catatan akuntansi yang digunakan dalam sistem informasi akuntansi penggajian pada PT. Bank Pembiayaan Rakyat Syariah Alwashliyah Medan hanya menggunakan jurnal umum. Dalam melakukan penjurnalan penggajian PT. Bank Pembiayaan Rakyat Syariah Alwashliyah Medan belum menerapkan bukti memorial dan kartu penghasilan karyawan sebagai dokumen untuk pencatatan penggajian.

\section{Daftar Pustaka}

Ambarita. Sistem Informasi Akuntansi Penggajian pada PT. Wesly Tour \& Travel. Medan: STIE IBMI, 2014.

Arikunto, Suharsimi. Prosedur Penelitian Suatu Praktek. Jakarta: Rineka Cipta, 2010.

Badrudin. Dasar - dasar Manajemen. Bandung: Penerbit Alfabeta, 2014. 
Bayangkara, IBK. Manajemen Audit Prosedur dan Implementasi. Jakarta: Penerbit Salemba Empat, 2009.

Bodnar dan William S. Hopwood. Sistem Informasi Akuntansi. Edisi 9.Yogyakarta: Penerbit Andi, 2010.

Diana, Anastasia dan Lilis Setiawati. Sistem Informasi Akuntansi. Yogyakarta: Penerbit Andi, 2011.

Dolok Saribu. Analisis Sistem Informasi Akuntansi Penggajian pada CV. Sartika Group. Medan: STIE IBMI, 2015.

Hall, James A. Sistem Informasi Akuntansi. Edisi 4. Jakarta: Salemba Empat, 2009.

Handoko, Hani. Manajemen. Edisi 2. Yogyakarta: Penerbit BPFE, 2012.

Hasibuan, Malayu S.P . Manajemen Sumber Daya Manusia. Jakarta: Penerbit Bumi Aksara. 2008.

Heizer, jay dan Barry Render. Management Operation. Edisi 9. Jakarta: Penerbit Salemba Empat, 2009.

Hongren, Charles dan Walter T. Harison. Akuntansi. Jilid 1. Jakarta: Penerbit Erlangga, 2011.

Jerry. Pengantar Akuntansi. Jakarta: Penerbit Salemba Empat, 2009.

Jusup, Al Haryono. Dasar-dasar Akuntansi. Jilid 1 edisi 7. Yogyakarta: STIE YKPN. 2011

Kristiana, Yuyun. Efektivitas Sistem Akuntansi Penggajian Karyawan PT. Imperium Jaya Perkasa. http://ejournal.stiesia.ac.id. (Diakses tanggal 03 Januari 2017).

Lapoliwa, N dan Daniel S Kuswandi. Akuntansi Perbankan. Edisi 6. Jakarta: Institut Bankir Indonesia, 2012.

Lubis, Arfan Ikhsan. Akuntansi Keperilakuan. Edisi 2. Jakarta: Penerbit Salemba Empat, 2010.

Mardi. Sistem Informasi Akuntansi. Bogor: Penerbit Ghalia Indonesia, 2011.

Mardiyasmo. Akuntansi Sektor Publik. Yogyakarta: Andi Offset, 2009.

McLeod, Raymond Jr dan George P. Schell. Sistem Informasi Manajemen. Edisi 10. Jakarta: Penerbit Salemba Empat, 2008.

Mulyadi. Sistem Akuntansi. Edisi 6. Jakarta: Penerbit Salemba Empat, 2013.

Mulyanto, Agus. Sistem Informasi Konsep dan Aplikasi. Pustaka Pelajar, 2009. 
Yurmaini dan Khairil: Analisis Efektivitas Sistem Informasi Akuntansi $\mid 435$

Romney, Marshal B \& Paul John Steinbard. Accounting Information System. Buku 1, Edisi 9. Jakarta: Penerbit Salemba Empat, 2011.

Siswanto, HB. Pengantar Manajemen. Edisi 3. Jakarta: Penerbit Bumi Aksara, 2007.

Sujarweni, V. Wiratna. Sistem Akuntansi. Yogyakarta: Pustaka Baru Press, 2015.

Supranti. Analisis Sistem Penggajian terhadap Efektifitas dan efisiensi Sistem Informasi Akuntansi Pembayaran Gaji Guru dan Karyawan pada Sekolah Menengah Kejuruan Muhammadyah I Somoroto. http:/leprints.umpo.ac.id (Diakses 03 Januari 2017).

Tampubolon, Bantu dan Halomoan Sihombing. Akuntansi Keuangan. Edisi Revisi. Medan: Universitas HKBP Nomensen, 2007.

Widyasari. Analisis Efektifitas Sistem Informasi Akuntansi Penggajian Karyawan pada RSUD Kota Semarang. http://www.eprints.undip.ac.id. pdf-adobe reader, 2012 (Diakses tanggal 01 Januari 2017).

\section{Endnote}

${ }^{1}$ Mulyadi. Sistem Akuntansi. Edisi 6. (Jakarta: Penerbit Salemba Empat, 2013), hlm. 382.

2 Ibid, hlm. 385-386.

${ }^{3}$ Marshal B Romney dan \& Paul John Steinbard. Accounting Information System. Buku 1, Edisi 9. (Jakarta: Penerbit Salemba Empat, 2011), hlm. 189.

${ }^{4}$ Mulyadi. Sistem Akuntansi. Edisi 6. (Jakarta: Penerbit Salemba Empat, 2013), hlm. 17.

${ }^{5}$ Ibid, hlm. 386-387.

${ }^{6}$ Ibid, hlm. 60-63. 